\title{
Structure and functions of Polychaetofauna living in Mytilus galloprovincialis assemblages in Thermaikos Gulf (north Aegean Sea)
}

\author{
Panagiotis DAMIANIDIS *, Chariton-Charles CHINTIROGLOU \\ Aristotle University of Thessaloniki, School of Biology, Department of Zoology, Box. 134, \\ 54006 Thessaloniki (Macedonia), Greece
}

Received 11 October 1999; revised 1 February 2000; accepted 4 February 2000

\begin{abstract}
The purpose of this study is to examine the Polychaetes populations of the mussel Mytilus galloprovincialis Lamarck 1819 assemblage in Thessaloniki Bay (Perea, Neoi Epivates, Agia Triada) in space and time. Forty-eight Polychaetes species, which belong to 16 families, were identified among 10593 individuals. The different distribution in space and time can be attributed to the life cycles of the Polychaetes, and also to the various biotic interactions. In general, the abundance follows the succession of the seasons, with some deviations though. Thus, the samples can be divided into two major groups, the winter and summer samples. The structure of the feeding guilds of the Polycheates population was also investigated and 9 different feeding guilds were identified. The microphagous, sedentary Polychaetes were the dominant guild, whilst the carnivores were the most abundant among the macrophagous. No major differences were observed, as regards the composition of the feeding guilds. The study of the structure of the polychaetofauna showed similar diversity with that of other Mediterranean regions. This fact implies that the polychaetofauna of the $M$. galloprovincialis assemblages in the Mediterranean Sea has a stable structure and shows a certain resemblance. Furthermore, the polychaetofauna includes species known as capable of living in polluted water as well as others that are more sensitive in such conditions. Therefore, the biomonitoring of the examined regions proves to be essential for obtaining valuable information about the state of their waters. (C) 2000 Ifremer/CNRS/IRD/Éditions scientifiques et médicales Elsevier SAS
\end{abstract}

Polychaeta / infralittoral / hard substratum / trophic relations / Aegean Sea

Résumé - Structure et fonction des Annélides Polychètes des assemblages de Mytilus galloprovincialis dans le golfe de Thermaikos (mer Egée Nord). Le but de la présente étude concerne l'examen de la population des Annélides Polychètes de la moule Mytilus galloprovincialis Lamarck 1819 dans la baie de Salonique (Perea, N. Epivates et Agia-Triada) dans ses dimensions spatiale et temporelle. Pour un total de 10593 individus, 48 espèces de Polychètes ont été déterminées, représentant 16 familles. L'abondance des Polychètes présente des variations en fonction de l'espace et du temps, ce qui est lié à leur cycle de vie, outre des interractions biotiques qui se développent entre les Polychètes et les autres organismes. Les variations de l'abondance suivent la succession des saisons. Ainsi, les échantillons se regroupent en deux groupes principaux, en fonction de la saison. Parallèlement, une étude de la structure des types trophiques des Polychètes a été réalisée. Cette partie de notre étude a mis en évidence la présence de neuf types trophiques. Au groupe principal, appartiennent les microphages, Polychètes sédentaires, tandis que, parmi les macrophages, dominent les carnivores. Les échantillons ne se différencient pas significativement en fonction de la constitution des types trophiques. L'étude de la constitution de la faune des Polychètes a mis en evidence une variabilité (nombre des espèces, indice de Shannon, stabilité)

\footnotetext{
* Correspondence and reprints: damian@bio.auth.gr
}

(C) 2000 Ifremer/CNRS/IRD/Éditions scientifiques et médicales Elsevier SAS

PII: S0399-1784(00)00127-4/FLA 
similaire à celle observée dans d'autres régions de Méditerranée, fait en faveur de la stabilité et de l'homiomorphie des phases de M. galloprovincialis en Méditerranée. En même temps, la constitution de la faune des Polychètes comporte des espèces caractérisées par leur résistance vis-à-vis de la pollution, et des espèces sensibles à la pollution. Cette observation indique que la «biosurveillance» de la phase de $M$. galloprovincialis peut fournir des informations considérables quant à la pureté des eaux. (C) 2000 Ifremer/CNRS/IRD/Éditions Scientifiques et médicales Elsevier SAS

\section{Polychètes / zone infralittorale / substrat rocheux / relations trophiques / mer Égée}

\section{INTRODUCTION}

The assemblages of $M$. galloprovincialis belong to those that can develop in polluted, moderately polluted and clean waters $([5,6,21,23,25,31,35,37$, 38 ] and others). Therefore, the biomonitoring of these assemblages can be a reliable source of information about the impact of pollution on hard substrate assemblages. According to Wenner [40], the structure of mussel communities can be a powerful bioindicator in the biomonitoring of the pollution of degraded marine areas.

There is adequate information about the structure of M. galloprovincialis assemblages from various regions in the Mediterranean Sea, especially from the western Mediterranean coasts [5-7, 15, 16, 27, 28, 36-38]. However, the information on the Aegean Sea is relatively limited. The first attempts to deal with this issue were published by Kocatas [23] and Topaloglou and Kihara [35].

In recent years, a research team of the Aristotle University of Thessaloniki has been funded by the Greek Ministry of Development to conduct a scientific programme to evaluate pollution in the Thermaikos Gulf, based on the examination of the composition of the artificial hard substrate in the Gulf. A part of this research was completed and published $[12,26]$ as preliminary results on the structure of $M$. galloprovincialis populations. In addition, Lantzouni [25] and Damianidis and Chintiroglou [14] provided further information on the structure of the amphipodofauna and the Polychaetofauna of these assemblages, respectively.

The aim of this study was to gather certain facts about the structure and functions of the Polychaetofauna living in the Mytilus galloprovincialis assemblage on the eastern coast of Thessaloniki Bay. These facts are essential for the support of a pollution biomonitoring programme in Thermaikos Gulf, which is heavily affected by industrial and urban waste.

\section{MATERIALS AND METHODS}

\subsection{Selection of the sampling sites}

The selection of the three sampling sites was based on their historical background, as well as on the exposure of the Mytilus galloprovincialis assemblages and the depth where they had settled. Out of all areas along the east coast of Thessaloniki Bay with artificial hard substrate, three appeared to show an equal bathymetric distribution of the $M$. galloprovincialis populations and corresponding exposure; they were the piers of Agia Triada, Neoi Epivates and Perea (figure 1). These piers were constructed 25 years ago, made of cement and based on a number of verticallybuilt cement columns, which constitute the substrate for the growth of the musselbeds. At these sampling sites the populations of $M$. galloprovincialis modulate a uniform physiognomic aspect, with great numbers of mussels occupying the area that extends from the lower level of the infralittoral zone down to a depth of $2.5 \mathrm{~m}$.

\subsection{Physico-chemical factors}

During this study, factors such as salinity, conductivity, water clarity, dissolved oxygen, temperature and total hydrodynamics were measured. All measurements were made with a WTW salinity-conductivity- $\mathrm{O}_{2}$-meter and Lovibond Checkit ( $\mathrm{pH}$-meter) micro-electronic equipment. The water transparency 
was determined with the Secchi disc. The evaluation of the effect of hydrodynamics according to Kaandorp [22] was based on the corrosion of plaster in the water. The measurements of the physico-chemical factors were conducted at each sampling site on a monthly basis.

\subsection{Sampling methods}

Sampling was carried out by Scuba diving. Samples were taken by means of the sampling methods described by Chintiroglou and Koukouras [10]. The area covered by this sampler is $400 \mathrm{~cm}^{2}(20 \times 20 \mathrm{~cm})$, which is the minimum necessary quadrate area for the investigation of the hard substrate [5, 31, 34, 39]. During each sampling period, 5 replicates were taken. The 60 samples, were collected during winter and summer of 1994 and 1995. After sampling, the specimens were preserved in a $10 \%$ formalin solution and were transferred to the laboratory for further treat- ment. The mussels contained in each sample were then counted and afterwards separately weighed, together with their shells, in order to estimate their average biomass. Tsuchiya and Nishihira [36] consider these data as important biotic factors for the composition of the $M$. galloprovincialis assemblages. All samples were collected by the same Scuba diver, so that the homomorphy of the sampling was guaranteed [3].

\subsection{Classification of the Polychaetes' feeding guilds}

The families of Polychaetes that have been identified in our samples have been classified in eight feeding guilds, based on the models of Fauchald and Jumars [17], and then divided into three categories. The first one divides the Polychaetes into macrophagous and microphagous, according to the quantity of food they consume. The second category divides them into carnivores and herbivores, and the third category in

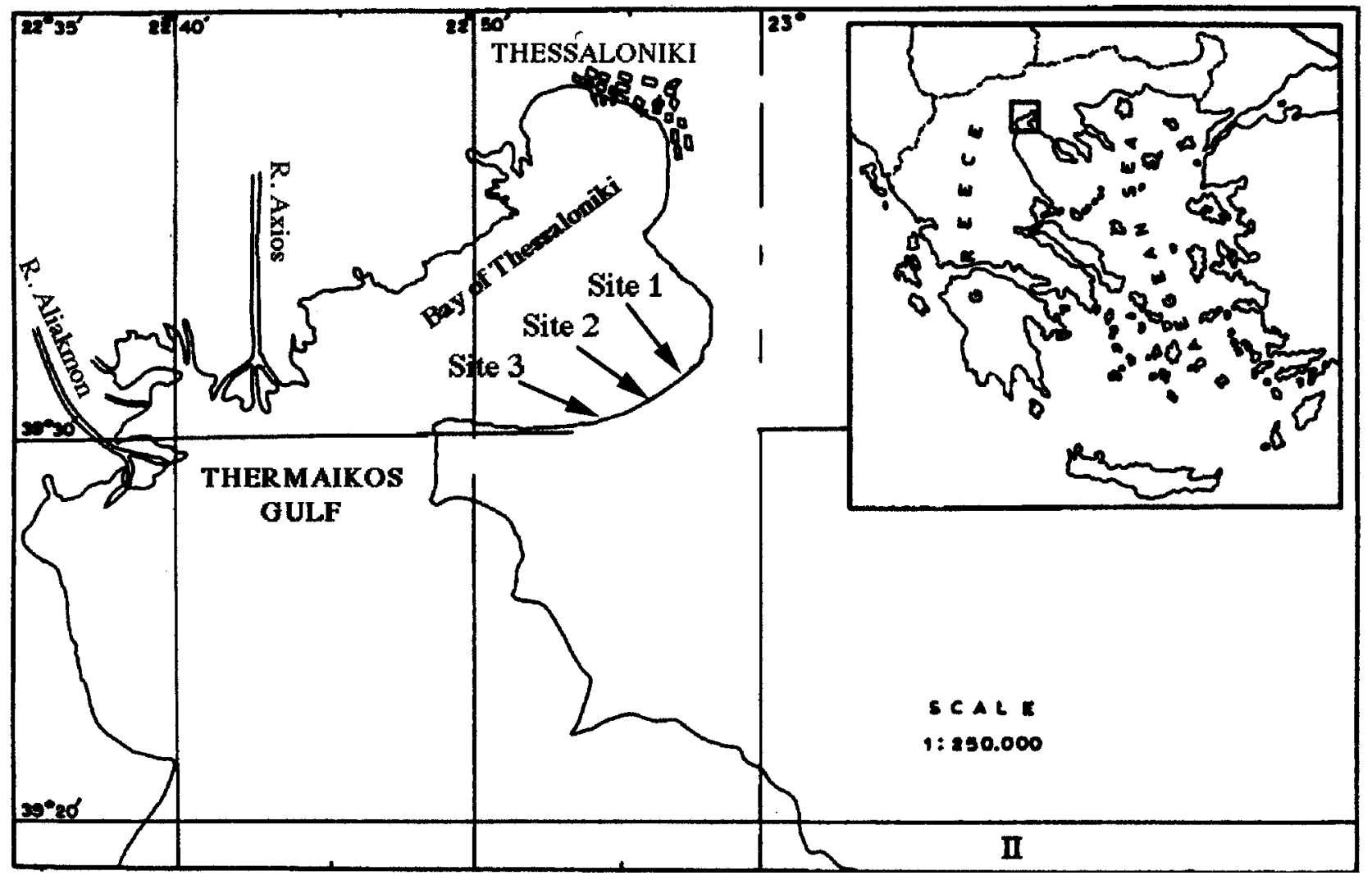

Figure 1. Map of the three sampling sites: Site $1=$ Perea $(P)$; Site $2=$ Neoi Epivates (NE); Site $3=$ Agia Triada (AT). 


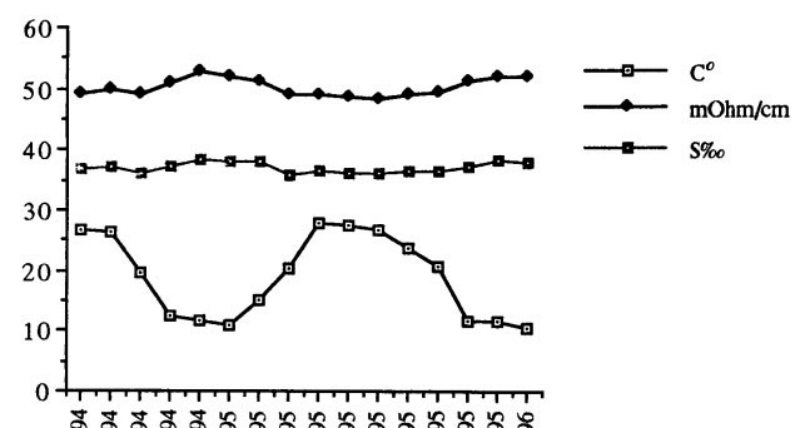

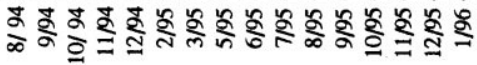
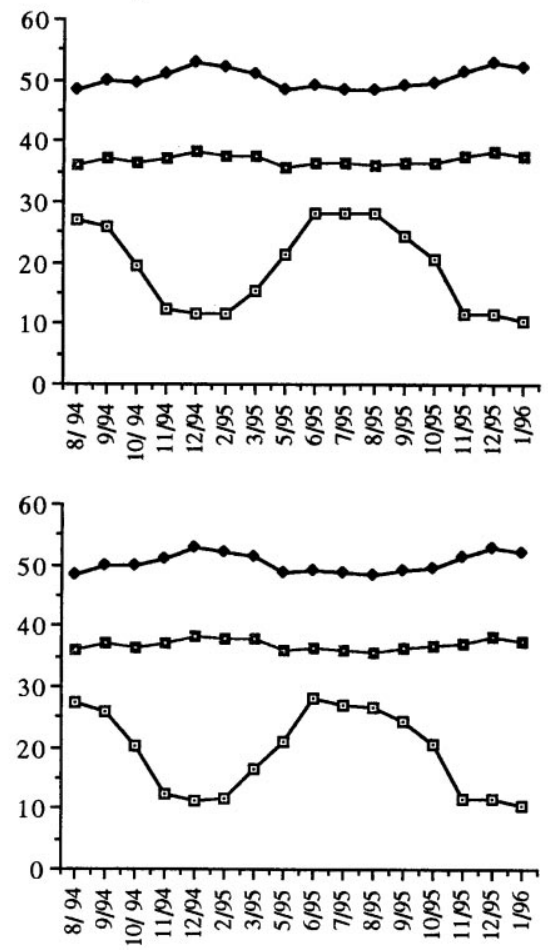

Figure 2. Results of the measurements of the main physico-chemical factors at each sampling site: temperature $\left({ }^{\circ} \mathrm{C}\right)$, conductivity $\left(\mathrm{mOhm} \cdot \mathrm{cm}^{-1}\right)$ and salinity $(\mathrm{S} \%)$.

motiles, discretely motiles and sessiles, according to the activity they show while consuming their food.

\subsection{Data analysis}

The presentation of the Polychaetofauna of the $M$. galloprovincialis assemblages was made by the methods proposed and used by Bellan-Santini [5], Soyer [33] and Marinopoulos [27]. This method compares species of different ecological groups in terms of bionomic coefficients. Species diversity $\left(\mathrm{H}^{\prime}\right)$ was calculated by Shannon's formula and evenness $\left(\mathrm{J}^{\prime}\right)$ was measured by the formula $\mathrm{H}^{\prime} / \log _{2} \mathrm{~S}[13,21,27]$. Seasonal differences in the mean numbers of individuals were tested using two-way and one-way Anova and multiple comparisons of mean values (Fisher PLSD test). All data were then converted to logarithms. The non-parametric test Spearman rank correlation coefficient $\left(r_{s}\right)$ [32] was used to determine the relationship between the number of mussels and their biomass with the abundance of the Polychaetofauna.

Eventually, the affinity of the sampling sites, in terms of the mean abundance of the samples, was determined with the use of the euclidean distance and the grouping coefficient of Ward's minimum-variance method. A similar methodology was followed by other studies of the hard substrate communities [6, $16,21]$.

\section{RESULTS}

\subsection{Physico-chemical characteristics of the stations}

\subsubsection{Conductivity, salinity and temperature}

Conductivity, salinity and temperature do not vary significantly in the three sampling stations (figure 2). In general, the pattern of the fluctuation of these values in time appears to be similar in all stations. The conductivity values do not show any significant fluctuation. On the other hand, the salinity values that were expected to reach their maximum in the summer months show their lowest values between May and October. The annual fluctuation of the measured salinity is in accordance with the facts presented by Anagnostou [1], Galinou-Mitsoudi [19] and Orfanidis [30]. These lower values appear to be the result of the inflow of freshwater from the estuary systems of the rivers Axios, Loudias, Aliakmon and Gallikos. The SSE winds, which are dominant in summer, lead these freshwater masses through surface currents to the eastern coast of Thermaikos Gulf $[20,24]$.

\subsubsection{Hydrodynamics}

As mentioned above, the degree of exposure, i.e. the intensity of hydrodynamics, is one of the most impor- 
tant factors involved in the study of the hard substrate communities.

The hydrodynamics effect is defined as the loss (\%) of weight observed in previously weighed plaster pieces. This method revealed that, during the period when the southern and southeastern winds dominate in the Thermaikos Gulf, the weight loss in Agia Triada and in Neoi Epivates was $48 \%$, while the corresponding value in Peraia was $65 \%$. These results indicate that the hydrodynamics effect is stronger in Peraia than in the other sites. However, these results are reversed when the winds blow in the opposite direction. The hydrodynamics effect is then stronger in Agia Triada and in Neoi Epivates than in Peraia.

\subsubsection{Water transparency}

The water transparency at the sampling sites could be characterized as satisfactory and at certain times even excellent, since the bottom was clearly visible at each biotope. It should be noted though that when SSE and NNW winds blow in the area, the water transparency is limited due to water turbulence and the incoming material from the northern coast.

\subsubsection{Dissolved oxygen and $p H$}

These two factors showed no significant fluctuation in time. With regard to $\mathrm{pH}$, the values varied around 8 , while the values for dissolved oxygen ranged from 6.5 to $8 \mathrm{ppm}$.

In conclusion, the abiotic factors measured in all sampling sites revealed a similar fluctuation in time. Therefore, eventual changes in the composition of the $M$. galloprovincialis assemblages should not be attributed to any of those factors.

\subsection{Polychaetofaunal composition}

48 Polychaete species were identified in this study (tables I, II, III), 27 of which can be characterized as very common, since their proportional representation in the total number of samples exceeds $50 \%$. Ten species, whose proportional representation ranges from $25 \%$ to $50 \%$, can be characterized as common.

- The presence of Prionospio (Prionospio) steenstrupi, the most frequently represented species in the $M$. galloprovincialis assemblage (18.1\%), is the most remarkable. Its mean and partial dominance are the highest in Peraia and Neoi Epivates and second in Agia Triada. This species is notably abundant in the summer samples and especially in the summer of 1994, whereas in the winter samples it is only found in small numbers. Generally, the presence of this species is imminently affected by its life cycle and its particular reproductive pattern that demands multiple reproductive efforts within a year [14, 18].

- There is one species that shows the highest mean abundance in summer samples, even though its general frequency in the total of the samples is not considerable $(7.5 \%)$. That is Schistomeringos rudolphii whose mean abundance reached $18.2 \%$ in the summer of 1995 in Neoi Epivates. The size of these individuals was notably small in these samples, probably as a result of a successful reproductive effort, which explains their high numbers.

The family with most species present in the samples is Serpulidae, which is represented by eight species; the most abundant of them is Serpula vermicularis (16.9\% in all samples). This species was found in every sample in all sampling sites. Its proportional representation is recorded as the second highest in Peraia and Neoi Epivates and as third in Agia Triada.

\subsection{Abundance and diversity of the Polychaetofauna}

\subsubsection{Abundance}

The comparison of the Polychaetes' abundance in time and in space was based on the examination of the null hypothesis that the abundance of the Polychaetes does not differ significantly (figures 3,4 ). The two-way and one-way Anova tests showed that the abundance of the Polychaetes is not equally distributed in the samples either in time or in space $(\mathrm{F}=2.5, \mathrm{df}=1 / 5, P=0.04)$. One-way Anova was used to detect the exact differences and showed an unequal distribution of the abundance of the Polychaetes in winter as well as in summer samples $(\mathrm{F}=$ 14.6, $\mathrm{df}=5 / 23, P=0.0001$ in winter samples and $\mathrm{F}=10.5, \mathrm{df}=5 / 22, P=0.0001$ in summer samples). Fisher PLSD test was also carried out in order to reveal those differences in winter samples and the result (Fisher PLSD, 0.4) indicated that all winter samples are significantly different, with the exception of some pairs of samples, more specifically PE.94/ 
Table I. Polychaetes of the M. galloprovincialis assemblage in the bay of Thessaloniki from the total number of samples at Peraia sampling site. Number of individuals ( $\left.\mathrm{N}^{\prime}\right)$, Mean abundance (Am), Partial mean dominance (Dmp), Shannon index $\left(\mathrm{H}^{\prime}\right)$ and Equitability index $\left(\mathrm{J}^{\prime}\right)$.

\begin{tabular}{|c|c|c|c|c|c|c|c|c|c|c|}
\hline \multirow[t]{2}{*}{ Polychaetofauna } & \multicolumn{2}{|c|}{ Winter 94} & \multicolumn{2}{|c|}{ Summer 94} & \multicolumn{2}{|c|}{ Winter 95} & \multicolumn{2}{|c|}{ Summer 95} & \multicolumn{2}{|c|}{ Total } \\
\hline & $\mathrm{Am}$ & Dmp & $\mathrm{Am}$ & Dmp & $\mathrm{Am}$ & Dmp & $\mathrm{Am}$ & Dmp & Am & Dmp \\
\hline Harmothoe impar & & & & & & & 0.40 & 0.42 & 0.50 & 0.10 \\
\hline Harmothoe reticulata & 2.40 & 3.66 & 5.40 & 3.06 & & & 0.40 & 0.42 & 10.25 & 2.07 \\
\hline Harmothoe spinifera & 11.00 & 16.77 & 0.60 & 0.34 & 1.20 & 2.08 & 2.00 & 2.09 & 18.50 & 3.74 \\
\hline Eumida sanguinea & 0.20 & 0.30 & 0.20 & 0.11 & 1.80 & 3.13 & 1.20 & 1.25 & 4.25 & 0.86 \\
\hline Genetyllis rubiginosa & 0.60 & 0.91 & 2.80 & 1.59 & & & 0.40 & 0.42 & 4.75 & 0.96 \\
\hline Kefersteinia cirrata & & & 13.60 & 7.71 & 4.60 & 7.99 & 22.40 & 23.38 & 50.75 & 10.27 \\
\hline Ophiodromus pallidus & & & 1.20 & 0.68 & 1.00 & 1.74 & & & 2.75 & 0.56 \\
\hline Syllidia armata & 11.00 & 16.77 & 23.60 & 13.38 & 0.40 & 0.69 & & & 43.75 & 8.85 \\
\hline Exogone naidina & 0.20 & 0.30 & & & & & & & 0.25 & 0.05 \\
\hline Syllis krohnii & 0.20 & 0.30 & & & & & & & 0.25 & 0.05 \\
\hline Syllis prolifera & & & 1.40 & 0.79 & & & 0.20 & 0.21 & 2.00 & 0.40 \\
\hline Ceratonereis costae & 0.20 & 0.30 & 0.20 & 0.11 & 1.80 & 3.13 & 0.40 & 0.42 & 3.25 & 0.66 \\
\hline Neanthes caudata & & & & & & & 0.20 & 0.21 & 0.25 & 0.05 \\
\hline Nereis zonata & 0.40 & 0.61 & 2.60 & 1.47 & 0.20 & 0.35 & & & 4.00 & 0.81 \\
\hline Platynereis dumerilii & 0.20 & 0.30 & & & 0.20 & 0.35 & & & 0.50 & 0.10 \\
\hline Lumbrineris coccinea & 0.40 & 0.61 & 0.20 & 0.11 & 0.40 & 0.69 & & & 1.25 & 0.25 \\
\hline Lumbrineris funchalensis & & & 1.00 & 0.57 & & & 0.60 & 0.63 & 2.00 & 0.40 \\
\hline Lysidice ninetta & & & 1.20 & 0.68 & 0.20 & 0.35 & 0.80 & 0.84 & 2.75 & 0.56 \\
\hline Marphysa fallax & & & & & & & 0.20 & 0.21 & 0.25 & 0.05 \\
\hline Marphysa sanguinea & 0.20 & 0.30 & 0.40 & 0.23 & & & & & 0.75 & 0.15 \\
\hline Nematonereis unicornis & 0.20 & 0.30 & & & & & 1.20 & 1.25 & 1.75 & 0.35 \\
\hline Schistomeringos rudolphii & 1.40 & 2.13 & 21.20 & 12.02 & 0.20 & 0.35 & 14.80 & 15.45 & 47.00 & 9.51 \\
\hline Polydora caeca & 0.80 & 1.22 & 0.20 & 0.11 & 0.20 & 0.35 & 1.40 & 1.46 & 3.25 & 0.66 \\
\hline Polydora ciliata & 1.40 & 2.13 & 0.40 & 0.23 & 0.40 & 0.69 & 2.80 & 2.92 & 6.25 & 1.26 \\
\hline Prionospio steenstrupi & & & 62.80 & 35.60 & & & 6.00 & 6.26 & 86.00 & 17.40 \\
\hline Cirriformia tentaculata & & & & & & & 0.20 & 0.21 & 0.25 & 0.05 \\
\hline Cirratulus sp. & & & 3.00 & 1.70 & 1.80 & 3.13 & & & 6.00 & 1.21 \\
\hline Chaetozone setosa & 1.40 & 2.13 & 0.60 & 0.34 & & & & & 2.50 & 0.51 \\
\hline Caulleriella alata & & & & & 0.40 & 0.69 & 2.60 & 2.71 & 3.75 & 0.76 \\
\hline Polyopthalmus pictus & 0.20 & 0.30 & & & 0.40 & 0.69 & & & 0.75 & 0.15 \\
\hline Capitella giardi & & & & & 0.40 & 0.69 & & & 0.50 & 0.10 \\
\hline Heteromastus filiformis & & & 0.20 & 0.11 & & & 3.40 & 3.55 & 4.50 & 0.91 \\
\hline Sabellaria spinulosa & 0.80 & 1.22 & 0.60 & 0.34 & 0.20 & 0.35 & 0.40 & 0.42 & 2.50 & 0.51 \\
\hline Amphitrite variabilis & 0.60 & 0.91 & 6.20 & 3.51 & 0.60 & 1.04 & 1.40 & 1.46 & 11.00 & 2.23 \\
\hline Terebella lapidaria & & & & & 1.20 & 2.08 & 12.00 & 12.53 & 16.50 & 3.34 \\
\hline Hydroides elegans & 0.20 & 0.30 & 2.20 & 1.25 & 10.20 & 17.71 & 6.20 & 6.47 & 23.50 & 4.75 \\
\hline Hydroides pseudouncinatus & & & 0.20 & 0.11 & & & 0.60 & 0.63 & 1.00 & 0.20 \\
\hline Hydroides uncinata & & & 0.20 & 0.11 & & & 0.20 & 0.21 & 0.50 & 0.10 \\
\hline Pomatoceros triqueter & 25.00 & 38.11 & 2.80 & 1.59 & 0.40 & 0.69 & 0.20 & 0.21 & 35.50 & 7.18 \\
\hline Serpula concharum & & & 0.60 & 0.34 & & & 0.20 & 0.21 & 1.00 & 0.20 \\
\hline Serpula vermicularis & 0.40 & 0.61 & 20.80 & 11.79 & 29.40 & 51.04 & 13.00 & 13.57 & 79.50 & 16.08 \\
\hline Spirobranchus polytrema & 6.20 & 9.45 & & & & & & & 7.75 & 1.57 \\
\hline Number of species & 29 & & 28 & & 24 & & 23 & & 42 & \\
\hline Number of individuals $\left(\mathrm{N}^{\prime}\right)$ & 882 & & 479 & & 328 & & 288 & & 1977 & \\
\hline Shannon Index $\left(\mathrm{H}^{\prime}\right)$ & 2.885 & & 3.141 & & 2.617 & & 3.54 & & 3.946 & \\
\hline Equitability Index $\left(J^{\prime}\right)$ & 0.517 & & 0.562 & & 0.469 & & 0.634 & & 0.707 & \\
\hline
\end{tabular}


Table II. Polychaetes of the M. galloprovincialis assemblage in the bay of Thessaloniki from the total number of samples at Neoi Epivates sampling site. Number of individuals $\left(\mathrm{N}^{\prime}\right)$, Mean abundance (Am), Partial mean dominance (Dmp), Shannon index $\left(\mathrm{H}^{\prime}\right)$ and Equitability index $\left(\mathrm{J}^{\prime}\right)$.

\begin{tabular}{|c|c|c|c|c|c|c|c|c|c|c|}
\hline \multirow[t]{2}{*}{ Polychaetofauna } & \multicolumn{2}{|c|}{ Winter 94} & \multicolumn{2}{|c|}{ Summer 94} & \multicolumn{2}{|c|}{ Winter 95} & \multicolumn{2}{|c|}{ Summer 95} & \multicolumn{2}{|c|}{ Total } \\
\hline & $\mathrm{Am}$ & Dmp & $\mathrm{Am}$ & Dmp & $\mathrm{Am}$ & Dmp & $\mathrm{Am}$ & Dmp & Am & Dmp \\
\hline Harmothoe impar & 1.80 & 0.52 & 0.25 & 0.04 & 0.8 & 0.7 & 0.60 & 0.18 & 4.25 & 0.26 \\
\hline Harmothoe reticulata & 1.00 & 0.29 & 29.75 & 4.75 & & & 2.40 & 0.71 & 34.00 & 2.09 \\
\hline Harmothoe spinifera & 1.80 & 0.52 & 0.75 & 0.12 & 7.00 & 6.12 & 4.40 & 1.30 & 17.25 & 1.06 \\
\hline Eumida sanguinea & 1.00 & 0.29 & 0.75 & 0.12 & 0.40 & 0.35 & 4.40 & 1.30 & 8.00 & 0.49 \\
\hline Phyllodoce rubiginosa & 3.00 & 0.87 & 2.50 & 0.40 & 1.80 & 1.57 & 0.80 & 0.24 & 9.50 & 0.58 \\
\hline Kefersteinia cirrata & & & 26.00 & 4.16 & 8.20 & 7.17 & 16.40 & 4.83 & 56.75 & 3.49 \\
\hline Ophiodromus pallidus & 3.60 & 1.04 & 9.25 & 1.48 & & & & & 13.75 & 0.85 \\
\hline Syllidia armata & 24.20 & 6.99 & 112.50 & 17.98 & 4.60 & 4.02 & 11.60 & 3.42 & 163.00 & 10.04 \\
\hline Autolytus prolifer & 0.40 & 0.12 & & & 0.40 & 0.35 & 1.20 & 0.35 & 2.50 & 0.15 \\
\hline Exogone naidina & 43.20 & 12.48 & 31.75 & 5.07 & 5.40 & 4.72 & 0.20 & 0.06 & 92.75 & 5.71 \\
\hline Syllis krohnii & & & 0.75 & 0.12 & & & & & 0.75 & 0.05 \\
\hline Syllis prolifera & 0.40 & 0.12 & 0.25 & 0.04 & & & & & 0.75 & 0.05 \\
\hline Ceratonereis costae & 8.40 & 2.43 & 6.25 & 1.00 & 3.20 & 2.80 & 5.60 & 1.65 & 27.75 & 1.71 \\
\hline Neanthes caudata & & & & & 0.20 & 0.17 & & & 0.25 & 0.02 \\
\hline Nereis zonata & 0.40 & 0.12 & 5.25 & 0.84 & 2.60 & 2.27 & 0.80 & 0.24 & 10.00 & 0.62 \\
\hline Perinereis cultrifera & & & & & & & 0.20 & 0.06 & 0.25 & 0.02 \\
\hline Platynereis dumerilii & & & 0.50 & 0.08 & 0.60 & 0.52 & 1.00 & 0.29 & 2.50 & 0.15 \\
\hline Lumbrineris coccinea & 1.60 & 0.46 & & & 0.60 & 0.52 & 1.00 & 0.29 & 4.00 & 0.25 \\
\hline Lumbrineris funchalensis & 0.20 & 0.06 & & & & & 0.20 & 0.06 & 0.50 & 0.03 \\
\hline Lysidice ninetta & 0.20 & 0.06 & 1.25 & 0.20 & & & 0.20 & 0.06 & 1.75 & 0.11 \\
\hline Marphysa fallax & 0.40 & 0.12 & 0.50 & 0.08 & & & & & 1.00 & 0.06 \\
\hline Nematonereis unicornis & 0.40 & 0.12 & 0.75 & 0.12 & 0.60 & 0.52 & 1.00 & 0.29 & 3.25 & 0.20 \\
\hline Schistomeringos rudolphii & 3.80 & 1.10 & 34.00 & 5.43 & 10.00 & 8.74 & 61.80 & 18.22 & 128.50 & 7.91 \\
\hline Polydora caeca & 33.60 & 9.71 & & & 0.60 & 0.52 & & & 42.75 & 2.63 \\
\hline Polydora ciliata & 1.20 & 0.35 & & & 0.60 & 0.52 & & & 2.25 & 0.14 \\
\hline Prionospio steenstrupi & 4.40 & 1.27 & 128.00 & 20.46 & 30.00 & 26.22 & 98.20 & 28.95 & 293.75 & 18.09 \\
\hline Cirratulus sp. & 27.40 & 7.91 & 90.00 & 14.38 & 21.60 & 18.88 & 7.40 & 2.18 & 160.50 & 9.88 \\
\hline Chaetozone setosa & 3.40 & 0.98 & & & & & & & 4.25 & 0.26 \\
\hline Polyopthalmus pictus & 2.00 & 0.58 & 1.50 & 0.24 & 2.60 & 2.27 & 6.20 & 1.83 & 15.00 & 0.92 \\
\hline Capitella capitata & & & & & 0.20 & 0.17 & & & 0.25 & 0.02 \\
\hline Capitella giardi & 0.20 & 0.06 & & & & & & & 0.25 & 0.02 \\
\hline Heteromastus filiformis & & & & & 0.40 & 0.35 & 24.80 & 7.31 & 31.50 & 1.94 \\
\hline Sabellaria spinulosa & 44.40 & 12.82 & 0.25 & 0.04 & 0.40 & 0.35 & & & 56.25 & 3.46 \\
\hline Amphitrite variabilis & 0.20 & 0.06 & 3.00 & 0.48 & 1.40 & 1.22 & 0.20 & 0.06 & 5.25 & 0.32 \\
\hline Terebella lapidaria & 0.60 & 0.17 & 3.25 & 0.52 & 2.40 & 2.10 & 2.60 & 0.77 & 10.25 & 0.63 \\
\hline Pseudopotamilla reniformis & & & & & 0.20 & 0.17 & 0.20 & 0.06 & 0.50 & 0.03 \\
\hline Hydroides dianthus & 1.40 & 0.40 & & & & & & & 1.75 & 0.11 \\
\hline Hydroides elegans & 23.00 & 6.64 & 7.00 & 1.12 & 2.20 & 1.92 & 33.40 & 9.85 & 80.25 & 4.94 \\
\hline Hydroides pseudouncinatus & & & 8.25 & 1.32 & 0.20 & 0.17 & & & 8.50 & 0.52 \\
\hline Pomatoceros triqueter & 21.40 & 6.18 & 5.25 & 0.84 & 3.00 & 2.62 & 0.20 & 0.06 & 36.00 & 2.22 \\
\hline Serpula concharum & & & 0.50 & 0.08 & 0.40 & 0.35 & & & 1.00 & 0.06 \\
\hline Serpula vermicularis & 80.20 & 23.17 & 115.50 & 18.46 & 1.80 & 1.57 & 52.20 & 15.39 & 281.75 & 17.35 \\
\hline Spirobranchus polytrema & 7.00 & 2.02 & 0.25 & 0.04 & & & & & 9.00 & 0.55 \\
\hline Number of species & 30 & & 28 & & 32 & & 31 & & 43 & \\
\hline Number of individuals $\left(\mathrm{N}^{\prime}\right)$ & 2503 & & 1696 & & 1731 & & 572 & & 6502 & \\
\hline Shannon Index $\left(\mathrm{H}^{\prime}\right)$ & 3.586 & & 2.063 & & 0.331 & & 3.16 & & 3.867 & \\
\hline Equitability Index $\left(J^{\prime}\right)$ & 0.642 & & 0.369 & & 0.059 & & 0.566 & & 0.692 & \\
\hline
\end{tabular}


Table III. Polychaetes of the M. galloprovincialis assemblage in the bay of Thessaloniki from the total number of samples at Agia Triada sampling site. Number of individuals $\left(\mathrm{N}^{\prime}\right)$, Mean abundance (Am), Partial mean dominance (Dmp), Shannon index $\left(\mathrm{H}^{\prime}\right)$ and Equitability index $\left(\mathrm{J}^{\prime}\right)$.

\begin{tabular}{|c|c|c|c|c|c|c|c|c|c|c|}
\hline \multirow[t]{2}{*}{ Polychaetofauna } & \multicolumn{2}{|c|}{ Winter 94} & \multicolumn{2}{|c|}{ Summer 94} & \multicolumn{2}{|c|}{ Winter 95} & \multicolumn{2}{|c|}{ Summer 95} & \multicolumn{2}{|l|}{ Total } \\
\hline & $\mathrm{Am}$ & Dmp & $\mathrm{Am}$ & Dmp & $\mathrm{Am}$ & Dmp & $\mathrm{Am}$ & Dmp & Am & Dmp \\
\hline Harmothoe areolata & 0.20 & 0.14 & 0.25 & 0.11 & & & 0.80 & 0.93 & 1.5 & 0.28 \\
\hline Harmothoe impar & 4.60 & 3.23 & 1.50 & 0.65 & 0.25 & 2.50 & 0.40 & 0.46 & 8.00 & 1.51 \\
\hline Harmothoe reticulata & & & 2.00 & 0.86 & & & 0.20 & 0.23 & 2.25 & 0.43 \\
\hline Harmothoe spinifera & 1.60 & 1.12 & & & & & 0.60 & 0.69 & 2.75 & 0.52 \\
\hline Eumida sanguinea & 0.80 & 0.56 & & & & & 0.20 & 0.23 & 1.25 & 0.24 \\
\hline Phyllodoce rubiginosa & 1.00 & 0.70 & 2.75 & 1.18 & 0.50 & 5.00 & 1.40 & 1.62 & 6.25 & 1.18 \\
\hline Kefersteinia cirrata & & & & & & & 12.00 & 13.89 & 15.00 & 2.84 \\
\hline Ophiodromus pallidus & 1.40 & 0.98 & 5.00 & 2.15 & & & 7.80 & 9.03 & 16.50 & 3.12 \\
\hline Syllidia armata & 2.80 & 1.96 & & & 0.50 & 5.00 & & & 4.00 & 0.76 \\
\hline Autolytus prolifer & & & & & 0.25 & 2.50 & & & 0.25 & 0.05 \\
\hline Exogone naidina & 2.00 & 1.40 & 2.00 & 0.86 & & & 2.20 & 2.55 & 7.25 & 1.37 \\
\hline Syllis prolifera & & & 1.00 & 0.43 & 0.25 & 2.50 & & & 1.25 & 0.24 \\
\hline Ceratonereis costae & 0.80 & 0.56 & & & 0.25 & 2.50 & 0.60 & 0.69 & 2.00 & 0.38 \\
\hline Nereis zonata & & & & & & & 2.00 & 2.31 & 2.50 & 0.47 \\
\hline Perinereis cultrifera & & & 0.50 & 0.22 & & & 1.00 & 1.16 & 1.75 & 0.33 \\
\hline Platynereis dumerilii & & & & & & & 0.20 & 0.23 & 0.25 & 0.05 \\
\hline Lumbrineris coccinea & 2.40 & 1.68 & & & 0.25 & 2.50 & 5.00 & 5.79 & 9.50 & 1.80 \\
\hline Lumbrineris funchalensis & & & 0.75 & 0.32 & & & & & 0.75 & 0.14 \\
\hline Lysidice ninetta & 0.20 & 0.14 & 4.00 & 1.72 & 0.25 & 2.50 & 1.00 & 1.16 & 5.75 & 1.09 \\
\hline Marphysa fallax & & & 0.25 & 0.11 & & & & & 0.25 & 0.05 \\
\hline Marphysa sanguinea & & & 0.25 & 0.11 & & & & & 0.25 & 0.05 \\
\hline Nematonereis unicornis & & & 0.25 & 0.11 & & & & & 0.25 & 0.05 \\
\hline Schistomeringos rudolphii & 0.20 & 0.14 & 10.00 & 4.31 & 0.25 & 2.50 & 9.20 & 10.65 & 22.00 & 4.16 \\
\hline Polydora caeca & 2.60 & 1.82 & 2.75 & 1.18 & & & 2.20 & 2.55 & 8.75 & 1.66 \\
\hline Polydora ciliata & 0.20 & 0.14 & 1.00 & 0.43 & 0.25 & 2.50 & & & 1.50 & 0.28 \\
\hline Prionospio steenstrupi & & & 92.00 & 39.61 & 0.25 & 2.50 & 6.40 & 7.41 & 100.25 & 18.97 \\
\hline Cirratulus sp. & 1.80 & 1.26 & 6.00 & 2.58 & 0.25 & 2.50 & 2.00 & 2.31 & 11.00 & 2.08 \\
\hline Caulleriella alata & & & & & & & 0.20 & 0.23 & 0.25 & 0.05 \\
\hline Polyopthalmus pictus & 0.20 & 0.14 & & & & & & & 0.25 & 0.05 \\
\hline Capitella capitata & & & & & & & 2.60 & 3.01 & 3.25 & 0.61 \\
\hline Capitella giardi & & & 2.50 & 1.08 & & & & & 2.50 & 0.47 \\
\hline Heteromastus filiformis & & & 0.25 & 0.11 & & & 1.00 & 1.16 & 1.50 & 0.28 \\
\hline Sabellaria spinulosa & 4.80 & 3.37 & 2.00 & 0.86 & & & & & 8.00 & 1.51 \\
\hline Amphitrite variabilis & 0.80 & 0.56 & 1.25 & 0.54 & & & 1.00 & 1.16 & 3.50 & 0.66 \\
\hline Terebella lapidaria & 1.00 & 0.70 & 3.25 & 1.40 & & & 2.00 & 2.31 & 7.00 & 1.32 \\
\hline Pseudopotamilla reniformis & & & 0.75 & 0.32 & 0.25 & 2.50 & 0.40 & 0.46 & 1.50 & 0.28 \\
\hline Hydroides elegans & 4.40 & 3.09 & & & 1.00 & 10.00 & & & 6.50 & 1.23 \\
\hline Hydroides pseudouncinatus & 2.80 & 1.96 & 9.00 & 3.88 & 1.75 & 17.50 & 19.00 & 21.99 & 38.00 & 7.19 \\
\hline Pomatoceros triqueter & 14.80 & 10.38 & & & & & & & 18.50 & 3.50 \\
\hline Serpula concharum & 4.40 & 3.09 & 13.00 & 5.60 & & & & & 18.50 & 3.50 \\
\hline Serpula vermicularis & 7.60 & 5.33 & 67.25 & 28.96 & 2.75 & 27.50 & 5.00 & 5.79 & 85.75 & 16.23 \\
\hline Spirobranchus polytrema & 79.20 & 55.54 & 0.75 & 0.32 & 0.75 & 7.5 & & & 100.50 & 19.02 \\
\hline Number of species & 25 & & 28 & & 17 & & 26 & & 42 & \\
\hline Number of individuals $\left(\mathrm{N}^{\prime}\right)$ & 713 & & 929 & & 40 & & 432 & & 2114 & \\
\hline Shannon Index $\left(\mathbf{H}^{\prime}\right)$ & 2.678 & & 2.809 & & 3.459 & & 3.795 & & 3.871 & \\
\hline Equitability Index $\left(J^{\prime}\right)$ & 0.479 & & 0.503 & & 0.619 & & 0.679 & & 0.693 & \\
\hline
\end{tabular}




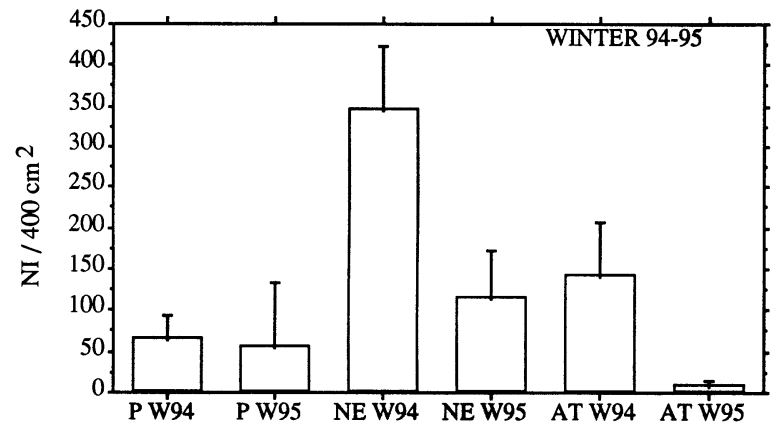

Figure 3. Fluctuation of the mean abundance of the Polychaetofauna during the winter months of 1994 and 1995, at the three sampling sites.

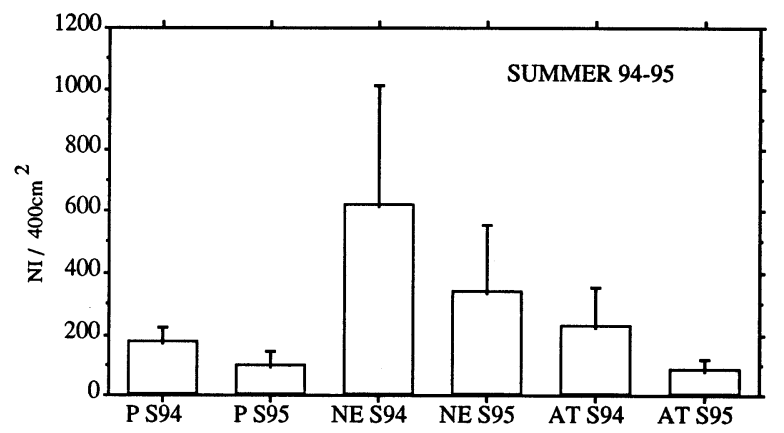

Figure 4. Fluctuation of the mean abundance of the Polychaetofauna during the summer months of 1994 and 1995, at the three sampling sites.

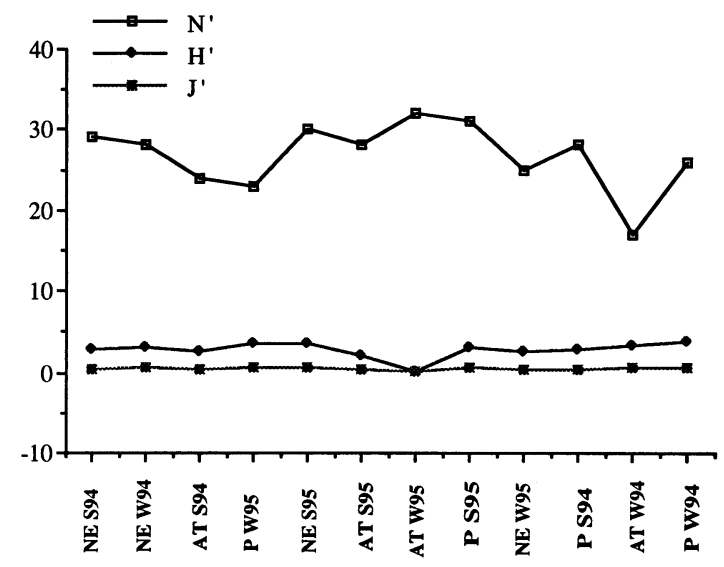

Figure 5. Number of Polychaetes species, Shannon index $\left(\mathrm{H}^{\prime}\right)$ and Equitability index $\left(\mathrm{J}^{\prime}\right)$ for each season and sampling site.

PE.95, PE.94/NE.95, PE.94/AT.94 and NE.95/AT.94, which do not show any significant difference (figure 3). The same test was employed for the summer samples and gave similar results (figure 4): 10 pairs of the 15 tested samples showed significant differences (Fisher
PLSD, 0.3), whereas the other 5 are homogeneous (PE.94/NE.95, PE.94/AT.94, PE.95/AT.95, NE.94/ NE.95 and NE.95/AT.94).

\subsubsection{Diversity}

The total number of Polychaete species found does not differ significantly from one sampling site to another. Forty-two species were found in Peraia, 43 in Neoi Epivates and 42 in Agia Triada. Likewise, the values of Shannon Index $\left(\mathrm{H}^{\prime}\right)$, as well as those of the equitability index $\left(\mathrm{J}^{\prime}\right)$ do not vary considerably among the three sampling sites (figure 5). The only significant variations are discovered in Agia Triada between the samples of winter 1995 and summer 1995. Nevertheless, the evenness factor, which varies around a value of 1 , indicates that the Polychaetofauna of the assemblage shows stability, with no significant fluctuations in space and in time, and also that there are species with similar presence in the assemblage. It should also be mentioned that the diversity index varies between values 2.5 and 3 , which corresponds with those of other related studies $[23,31]$.

\subsection{Relationships between the Polychaetofauna and the structure of the musselbeds}

According to Tsuchiya and Nishihira [36], the morphology and relative age of the mussels in an assemblage can play a significant role in the composition of the organisms that settle there. The older the mussels are in an assemblage, the larger is the number of the epifauna on the shells, since there are far more available habitats for settling. Therefore, the correlation between the abundance and the biomass of the mussels and the abundance and number of species of Polychaetes was examined so that the degree of interdependence of these parameters could be estimated.

The results showed that the abundance of the Polychaetofauna is not correlated with the abundance of the mussels or with their biomass $\left(\mathrm{r}_{\mathrm{s}}=0.3 P=0.07\right.$, $\mathrm{r}_{\mathrm{s}}=0.3 P=0.06$ respectively). In contrast, the number of species is related to the mussels' biomass and to their abundance $\left(\mathrm{r}_{\mathrm{s}}=0.4 \mathrm{p}=0.02, \mathrm{r}_{\mathrm{s}}=-0.4 P=0.04\right.$, respectively).

\subsection{Affinity of the sampling sites}

A study of the affinity of the samples based on the abundance of the populations of the Polychaetes 


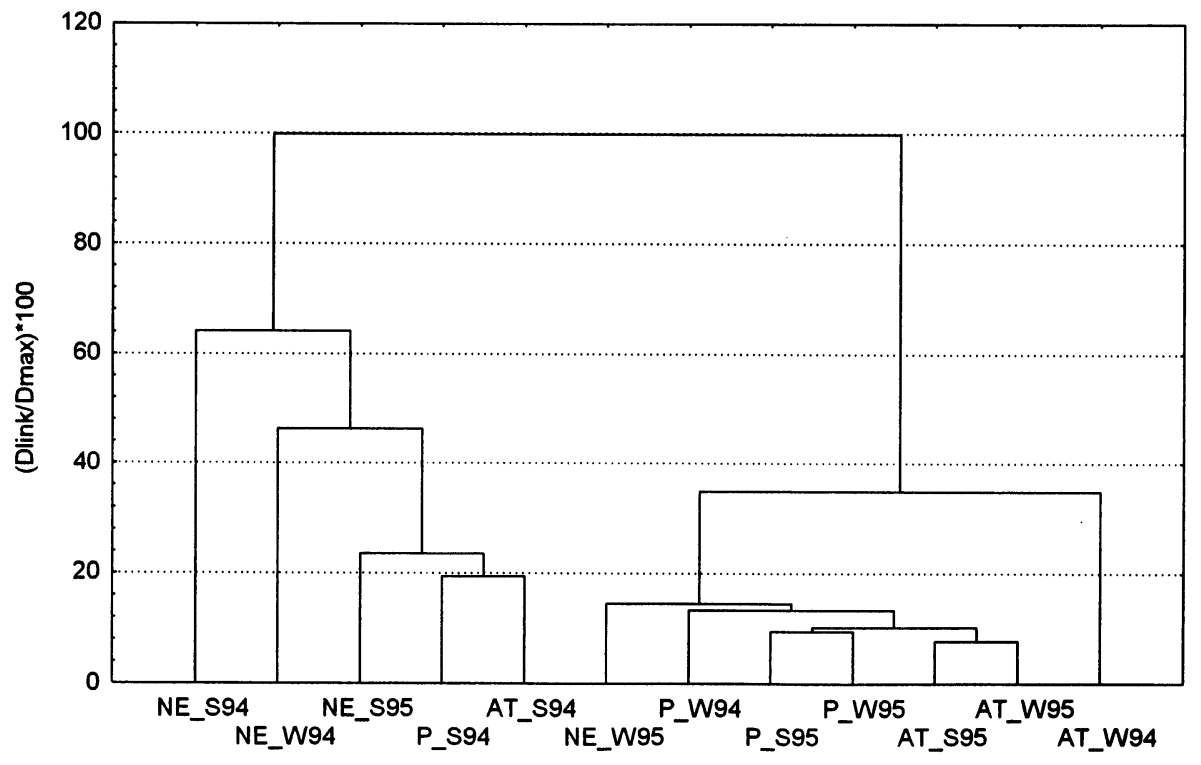

Figure 6. Dendrogramme (Euclidian distances, Ward's method) of the abundance of samples, presenting the seasonal affinity of the samples in the years 1994 and 1995.

showed that the samples are divided into two basic groups, which in general correspond to the two seasons (figure 6). Some of the samples, though, do not follow this pattern. The 1994 winter samples from Neoi Epivates are grouped together with the summer samples, whereas the 1995 summer samples from Peraia and Agia Triada are placed among the winter samples. As figure 7 and also the Anova test for the comparison of the abundance of the samples show, the 1994 winter samples of Neoi Epivates do not differ significantly from the rest of the summer samples, with the exception of the, likewise misplaced, 1995 summer samples of Peraia and Agia Triada. Similarly, the latter do not differ significantly from the rest of the winter samples.

With respect to the differentiations of the uneveness degree between samples of the same season, it was found to be higher in the summer samples than in winter samples. The degree of uneveness in the summer samples lies between 10 and $35 \%$, while in the winter samples between 20 and $65 \%$.

\subsection{Distribution of the Polychaetes' feeding guilds}

The total number of species are grouped into nine feeding guilds:

CMJ: carnivores, motile, with jawed pharynx;

CMX: carnivores, motile, without jawed pharynx;
HMJ: herbivores, motile, jawed;

BMJ: burrowers, motile, jawed;

FDT: filter-feeders, discretely motile, with tentacles;

SDT: $\quad$ surface deposit-feeders, discretely motile, tentaculate;

SST: $\quad$ surface deposit-feeders, sessile, tentaculate;

BMX: burrowers, motile, without jawed pharynx and FST: filter-feeders, sessile, tentaculate.

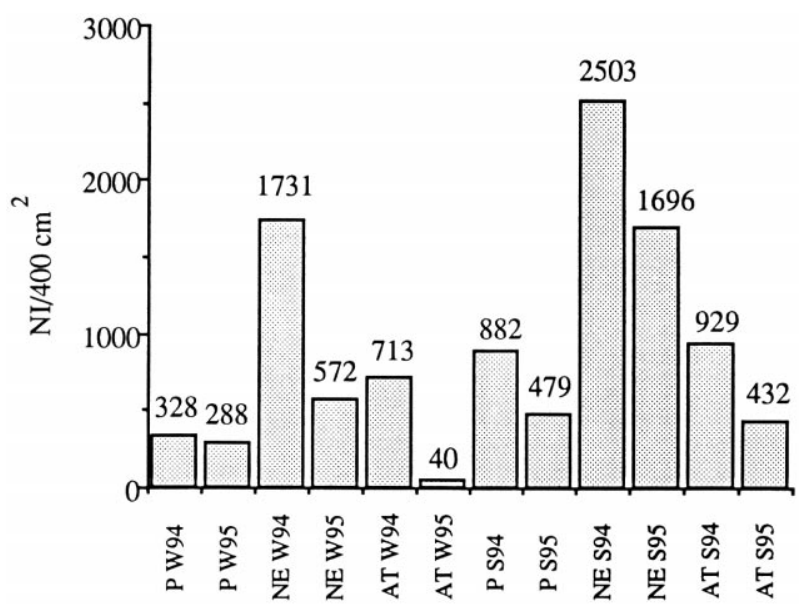

Figure 7. Abundance of the Polychaetofauna in space and in time. 


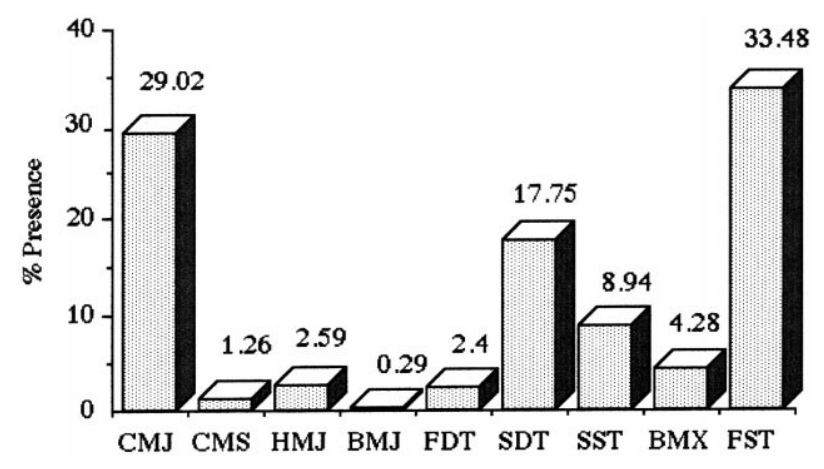

Figure 8. Mean dominance of the feeding guilds of the Polychaetes in the M. galloprovincialis assemblage in the bay of Thessaloniki.

Three of them are the most frequently observed in the assemblage (figure 8):

1. FST, reaching a percentage of $33.5 \%$, to which the families Sabellariidae, Sabellidae and Serpulidae belong;

2. CMJ, which is represented by the families Polynoidae, Phyllodocidae, Hesionidae, Syllidae, Dorvilleidae and Lumbrineridae, with a percentage of $29 \%$;

3. SDT which, in these samples, is exclusively represented by the species Prionospio (Prionospio) steenstrupi of Spionidae family, with a percentage of $17.8 \%$.

This classification of the Polychaetes according to the type and size of their food and their locomotory pattern shows that the abundance of the microphagous Polychaetes is considerably higher than that of the macrophagous ones, with a percentage of $67.1 \%$ and $32.9 \%$ respectively. The major part of the macrophagous (92.1\%) are carnivores, whereas the herbivores are represented in much smaller numbers $(8 \%)$.

The locomotory patterns of the Polychaetes are directly affected by their feeding habits. In this study the sessile microphagous Polychaetes were the most abundant $(42.4 \%)$, while the motile macrophagous were represented with a percentage of $37.4 \%$ and the surface deposit-feeders, discretely motile with $20.1 \%$. The latter, however, were preclusively represented by only one species of Spionids.

The abundance of the motile and carnivore Polychaetes is significantly low (figure 8), due to biotic interactivities (e.g. predation) between the organisms in the assemblage. For example, the presence of certain predators, such as the Crustacean decapods Pilumnus hirtellus, Pisidia longirostris and Pachygrapsus marmoratus, which appear quite frequently in the assemblage are able to consume large numbers of these Polychaetes (Damianidis and Chintiroglou, 1998). The herbivores, on the other hand, show only a small abundance, as expected in such assemblages where the growth of flora is very limited.

The examination of the degree of affinity between the samples regarding the abundance and composition of the feeding guilds of the Polychaetofauna led to the formation of two primary groups of samples (figure 9). The first group includes the summer samples of 1994 and 1995 and the winter samples of 1994 from Neoi Epivates, while the second group includes the rest of the samples. The differentiation level between the two groups does not exceed $25 \%$, which confirms the stable composition of the feeding guilds of the Polychaetofauna of the assemblage in space and in time. The formation of the first group from exclusively Neoi Epivates samples can be attributed to the notably high abundance of the Polychaetofauna (1953, 2503 and 1696 individuals) in those samples. The comparison of the abundance of the feeding guilds of these samples (NE. S94, NE. S95 and NE. W94) with all the rest revealed a significant difference $(<P=0.001)$ and confirmed this assumption.

\section{CONCLUSIONS}

The study of the Polychaetofauna of the assemblage of Mytilus galloprovincialis in the Bay of Thessaloniki led to the identification of 48 species of Polychaetes, which belong to 16 families. Twenty-seven of these species were characterized as very common, 10 as common and 11 as rare. In particular, the composition of the Polychaetofauna of the musselbeds showed similar diversity indices to those from other areas in the Mediterranean Sea. When compared to them, however, the number of species identified in the Bay of Thessaloniki (48) is much higher. A review of the relevant literature revealed that the number of species and other factors that refer to the biodiversity of the M. galloprovincialis assemblages in the Bay of 
Thessaloniki show some differentiations from the respective facts that other studies revealed in adjacent or other sites in the Mediterranean Sea. According to Kocatas [23], 35 species of Polychaetes were found in musselbeds in the Bay of Ismir, while Bellan-Santini [5] reported 14 species in clear water and 13 species in musselbeds of polluted waters. Saldanha [31] identified 33 species in various sites off Portugal's coastline, while Tsuchiya and Bellan-Santini [37] reported 33 in the region of Marseilles. Quite recently Topaloglou [35] mentioned only 10 species on musselbeds in the Bosphorus Channel. Consequently, this review indicates that the diversity of the Polychaetofauna of the musselbeds of artificial hard substrate on the eastern coasts of the Bay of Thessaloniki is very rich and so the structure of the assemblage is considered as good.

Further examination of the literature leads to some interesting conclusions. Many of the common species that were found by Kocatas [23] in Izmir Gulf were also frequently found in Thermaikos Gulf (Schistomeringos rudolphii, Hydroides elegans, Terebella lapidaria and Audinia tentaculata). Bellan-Santini [5] identified 25 species in corresponding mussel beds of the Gulf of Marseilles. Two of the most frequent (which were Syllis prolifera, Platynereis dumerilii, Perinereis cultrifera and Spirobranchus polytrema) be- long to the very common species of this study, while the other two belong to the common ones. Finally, in Saldanha's study [31] the species Lepidonotus clava, Eulalia viridis, Pomatoceros lamarckii, Syllis krohnii, Platynereis dumerilii and Lumbriconereis funchalensis are reported as very common. Only the last three are identified in our study $(P$. dumerilii and $L$. fuchalensis as very common species, and $S$. krohnii as rare). These differences with the samples examined by Saldanha [31], though from similar assemblages, should be put down to the fact that the samples originated from an entirely different geographical region (Portugal's coasts). Eventually, it should also be noted that a comparison with the results of other studies $[21,35$, $37,38]$ revealed no significant difference in the composition of the dominant species; this fact implies that the structure of the Polychaetofauna in the $M$. galloprovincialis assemblages in the Mediterranean Sea is homogeneous.

The study of the composition of the feeding guilds of the Polychaetes in the assemblage showed that the microphagous, sessile polychaetes are the most abundant. The carnivores predominate among the macrophagous. The particular composition of the feeding guilds covers most of the trophic levels required for the good function of an assemblage, so that the studied assemblage can be considered as well

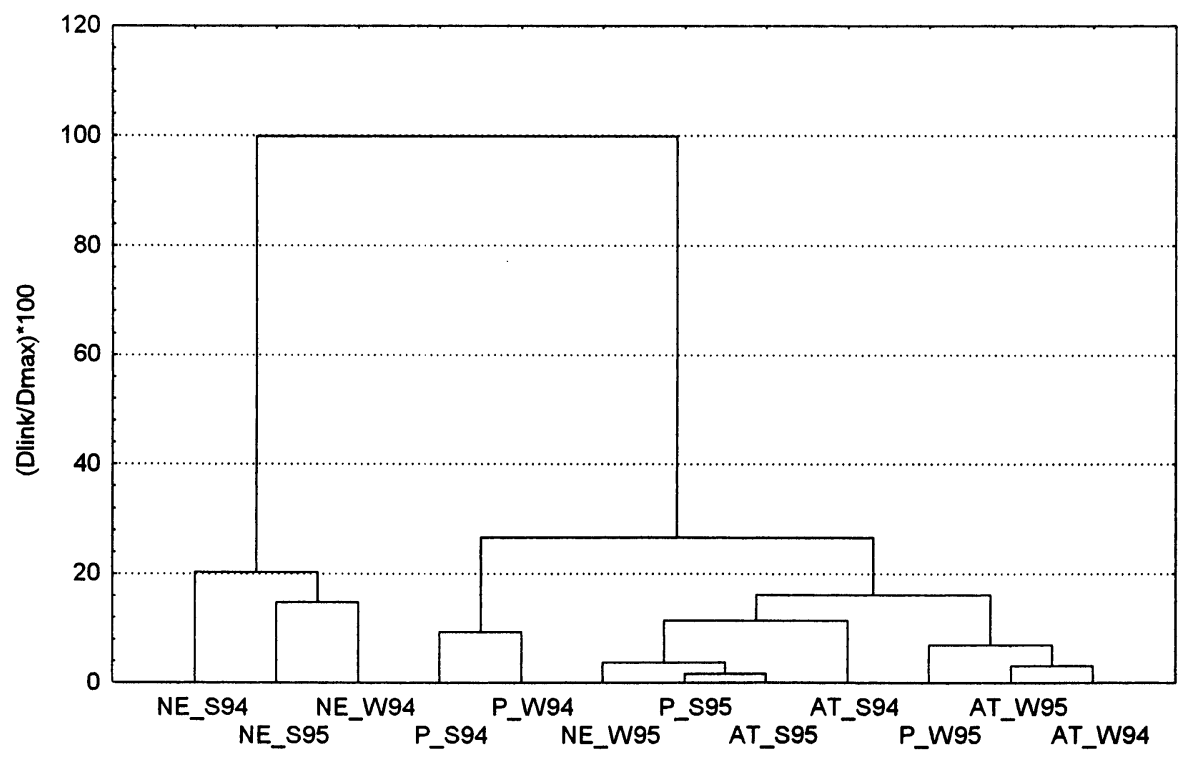

Figure 9. Dendrogramme (Euclidian distances, Ward's method) of the abundance of the feeding guilds of the Polychaetes in the samples, presenting their seasonal affinity in the years 1994 and 1995 . 
organized [16]. The dominance of the sessile/microphagous Polychaetes in the M. galloprovincialis assemblage can be considered as predictable, since all preconditions for their growth are fulfilled in this assemblage. Thus, the bivalves' shells offer an ideal surface for the settlement of the Polychaete larvae. The predominance of such species (e.g. Serpulids) is also favoured by the various patterns of reproduction that they employ (sexual, asexual, hermaphroditism), in combination with their long life cycle (6 to 8 years) $[8,18]$. Moreover, the locality of the sampling sites can guarantee the continuous service of their energy needs through suspension feeding. As recent studies report [2] the circulation of water masses in the Thermaikos Gulf, as formed under the influence of the local winds and upwelling currents, is responsible for an increase of the amount of organic and inorganic material in the water at the sampling sites. As a result, the growth of the suspension feeding Polychaetes and the filter-feeding bivalves as well can be secured with constant provision of food particles.

The proportions of the different feeding guilds found in the M. galloprovincialis assemblage is different to that of other benthic assemblages. Bianchi and Morri [9] noted that in the coastal dendritic assemblages detritivorous Polychaetes (i.e. Spionidae) constituted $18 \%$ of the total species and filter-feeders $10 \%$, whereas macrophagous (carnivores) exceeded $62 \%$. In photophylic algae assemblages the macrophagous are predominant as well $(46 \%)$, while the presence of discretely motile and microphagous Polychaetes is relatively limited (17\% and $19 \%$ respectively) (Bianchi and Morri, 1985). It is remarkable that the $M$. galloprovincialis assemblage does not follow the same pattern, even though it is actually a part of the photophylic algae assemblage. This particularity indicates that the surrounding assemblages do not influence the $M$. galloprovincialis assemblage, at least at the Polychaetes feeding guilds level.

The facts presented in this study seem to be in accordance with those reported by Chintiroglou [11] about the composition of the feeding guilds of the Polychaetes associated with the coral Cladocora caespitosa. In these assemblages the sessile, filter-feeding Polychaetes outnumber all other types of feeding guilds. In this case, the Polychaetofauna is influenced by multiple biotic parameters, such as the chemical barriers that prevent other organisms from settling. Although the two assemblages (Cladocora/Mytilus) significantly differ from each other on the grounds of ecology, biology and morphology, they show a certain similarity as far as the composition of the Polychaetes feeding guilds is concerned. This must be attributed to the substrate type (the hard substrate of coral colonies and mussel shells) that both assemblages offer for the settlement of the sessile and filter-feeding Polychaetes.

The structure of the musselbeds (biomass and number of mussels) influences the diversity of the Polychaetofauna significantly. This is the result of various biotic interactions between the organisms of the assemblage. These biotic interactions in the musselbeds are the cause of multiple differentiations and, therefore, should be taken into consideration in any study of these assemblages. These results are a clear indication that a large number of mussels enable the settlement of a relatively larger number of species of Polychaetes, as the number of habitats created among the mussels increases in proportion. This increased number of species may lead to interspecific interactions, which will subsequently limit the growth rate of their populations. On the other hand, when the size, the biomass of the mussels increases, it is very possible for larger organisms to settle there. This may have a negative impact on the abundance of the Polychaetes populations, due to predation by larger carnivorous and omnivorous organisms (e.g., sea anemones, decapods, ascidians, fish). Therefore, it seems that the diversity of the Polychaetofauna is influenced by the structure of mussel populations. The research conducted by Tsuchiya and Nishihira [36] on M. edulis populations in the Pacific Ocean, concluded similar results, as regards the relationships that develop between the age of the mussels and the diversity of the organisms settled on the musselbeds. However, the authors did not examine more specific biotic interactions (predation, territoriality, etc.), which also develop and affect, in a negative or positive way, these organisms which settle on the lower levels of the trophic web of the musselbeds. The above observations suggest that such relationships should be taken into consideration in any kind of research that deals with the structure and function of assemblages, especially in the case of hard substrate assemblages. 
In general, the abundance of the Polychaetes is unequally distributed in space and in time. Even though it is difficult to give a clear explanation of these differentiations, they should be attributed to biotic interactions between the Polychaetofauna and the musselbeds in their structure. As mentioned before, an increase in the abundance of mussels affects the diversity of the Polychaetofauna positively, whereas an increase in the biomass has the opposite effect. In conclusion, the fact that the samples are divided into two groups (winter-summer) indicates that the abundance of the Polychaetes of the assemblage follows, in general, the succession of the seasons, with certain differentiations, which should be examined on a basis of biotic interactions.

Finally, according to Bellan [4], several of the Polychaetes species in this assemblage are sensitive to pollution (e.g. Schistomeringos rudolphii). This fact implies that the biomonitoring of this assemblage can lead to useful conclusions on the extension of pollution in the Bay of Thessaloniki [40]. Though the three sampling sites are located far from the industrial zone of Thessaloniki in the northwest of the bay (figure 1), they have become a tank for the sewage from the nearby fast-developing urban area. Therefore, the waters there are characterized as belonging to an intermediate level of pollution [29]. A biomonitoring programme, that will cover the Bay to its full extent, is required in order to determine whether the condition worsens or not. The facts presented in this study, along with those from the rest of the studies from the same programme, can play a basic role in such an attempt.

\section{Acknowledgements}

We wish to thank the Hellenic Ministry of Development, General Secretariat for Research and Technology, for the financial support of this research.

\section{REFERENCES}

[1] Anagnostou C., Kontogiannis C., Papadopoulos V., Formation of the benthic nepheloid layer in the inner Thermaikos Gulf (Greece), Proc. 5th Hel. Symp. Oceanogr. Fish. 1 (1997a) $51-54$.
[2] Anagnostou C., Georgakopoulou-Gregoriadou E., Zenetos A., Kamberi E., Karageorgis A., Kontogiannis C., Pagou K., Panagiotidis P., Pancucci A., Siokou I., Symboura N., Chatjanestis I, Psyllidou-Giuranovits R., The state of the marine ecosystem of the bay and the Gulf of Thessaloniki - The reaction capacity of the system, Proc. 5th Hel. Symp. Oceanogr. Fish. 1 (1997b) 83-86.

[3] Bakus G.J., Quantitative Ecology and Marine Biology, A.A. Balkema, Rotterdam, 1990, 157 p.

[4] Bellan G., Relationship of pollution to rocky substratum polychaetes on the French Mediterranean coast, Mar. Poll. Bull. 11 (1980) 318-321.

[5] Bellan-Santini D., Contribution à l'étude des peuplements infralittoraux sur substrat rocheux (Etude qualitative et quantitative de la frange supérieure), Rec. Trav. Stat. Mar. Endoume 47 (63) (1969) 5-294.

[6] Bellan-Santini D., Influence des pollutions sur le peuplement des amphipodes dans la biocénose des algues photophiles, Téthys 10 (1981) 185-194.

[7] Bellan-Santini D., Desrosiers G., Action du rejet thermique de l'usine de Martigues-Ponteau sur les peuplements de substrats durs à dominance de zoobenthos dans la partie supérieure de l'étage infralittoral, Téthys 8 (1981) 83-92.

[8] Bianchi N.C., Guide per il riconoscimento delle species animali delle acque lagunari e costiere italiane, AQ/1/96, 5, Policheti Serpuloidei, Consiglio Nazionale delle Ricerche, (1981) $187 \mathrm{p}$.

[9] Bianchi N.C., Morri C., I policheti come descrittori della struttura trofica degli ecosistemi marini, Oebalia 11 (1985) $203-214$.

[10] Chintiroglou C., Koukouras A., A population of the sea anemone Anemonia viridis (Förskal, 1775) and its associated flora and fauna in the North Aegean Sea, Int. Revue ges. Hydrobiol. 77 (1992) 483-495.

[11] Chintiroglou C., Feeding guilds of Polychaetes associated with Cladocora caespitosa (L.) (Anthozoa, Cnidaria) in the North Aegean Sea, Israel J. Zool. 42 (1996) 261-274.

[12] Chintiroglou C., Christidis G., Skoufas G., Karalis P., Loukmidou S., Antoniadou C., Lantzouni M., Abundance of Mytilus galloprovincialis Lam., 1819 on the eastern shores of Thessaloniki Bay, Proc. 5th Hel. Symp. Oceanogr. Fish. 2 (1997) 103-106.

[13] Daget J., Les modèles mathèmatiques en écologie, collection d'écologie, Masson, Paris, 1979, 172 p.

[14] Damianidis P., Chintiroglou C., Feeding guilds of polychaetes associated with Mytilus galloprovincialis Lam. assemblage in the North Aegean Sea, Rapp. Comm. Int. Mer Médit. 35 (1998) 416-417.

[15] Desrosiers G., Bellan-Santini D., Brethes J.-C., Évolution spatio-temporelle des peuplements de substrats rocheux superficiels dans un golfe soumis à de multiples pollutions (golfe de Fos, France), Téthys 10 (1982) 245-253.

[16] Desrosiers G., Bellan-Santini D., Brethes J.-C., Organisation trophique de quatre peuplements de substrats rocheux selon un gradient de pollution industrielle (golfe de Fos, France), Mar. Biol. 91 (1986) 107-120. 
[17] Fauchald K., Jumars P.A., The diet of worms: a study of polychaetes feeding guilds, Oceanogr. Mar. Biol. Ann. Rev. 17 (1979) 193-284.

[18] Fauchald K., Life diagram patters in benthic polychaetes, Proc. Biol. Soc. Wash. 96 (1) (1983) 160-177.

[19] Galinou-Mitsoudi S., Sinis A.I., Petridis D., Reproduction of Venus verrucosa in the Thessaloniki and Thermaikos gulfs, Proc. 5th Hel. Symp. Oceanogr. Fish 2 (1997) 107-110.

[20] Gannulis J., Krestenitis J., Choix du site optimum d'evacuation des eaux usées dans une région côtière, Société Hydrothermique de France, XVIIemes Journées de l'Hydraulique 9 (1982) 1-6.

[21] Hong J.S., Impact of the Pollution on the Benthic Community, Bull. Korean Fish. Soc. 16 (1983) 273-290.

[22] Kaandorp J.A., Rocky substrate communities of the infralittoral fringe of the Boulonnais coast, NW France: a quantitative survey, Mar. Biol. 92 (1986) 255-265.

[23] Kocatas A., Contribution à l'étude des peuplements des horizons supérieurs de substrat rocheux du golfe d'Izmir (Turquie), Ege Univ. Fen Fak. Monogr. Seri. 12 (1978) 1-93.

[24] Krestenitis Y.N., Christopoulos S.P., Valioulis I.A., Hyder P., The study of the region of fresh water influence of Thermaikos Gulf, Proc. 5th Hel. Symp. Oceanogr. Fish 1 (1997) $47-49$.

[25] Lantzouni M., Voultsiadou E., Chintiroglou C., Preliminary observations on amphipod assemblages associated with Mytilus galloprovincialis Lam. beds from Thermaikos Gulf (Aegean Sea), Rapp. Comm. Int. Mer Médit. 35 (1998) 458459.

[26] Le Breton S., Chintiroglou C., Structure of Mytilus galloprovincialis Lamarck 1819 populations in Thessaloniki bay, Rapp. Comm. Int. Mer Médit. 35 (1988) 558-559.

[27] Marinopoulos J., Étude des peuplements infralittoraux de substrats rocheux de la région de Marseille et des facteurs abiotiques (lumière, hydrodynamique) les influençant, Thèse Univ. Aix-Marseille II, 1988.

[28] Matarrese A., Tursi A., Constantino G., Pollicoro R., The reproductive cycle of Mytilus galloprovincialis Lam. in the Mar Piccolo and in the Mar Grande of Taranto (Ionian Sea), Oebalia 19 (1993) 1-11.

[29] Nikolaidis G., Der Einfluss Häuslicher und industrieller Abwässer auf die Biomasse und die Zusammensetzung der epilithischen Algengesellschaften der Makrophyten des Eulitorals und des oberen Sublitorals im Golf von Thessaloniki, Griechenland, Nova Hedwigia 45 (1987) 147-168.

[30] Orfanidis S., Lazaridou E., Seferlis M., Haritonidis S., Eutrophication and the abundance of seaweeds in the biotope of Agia Triada, Gulf of Thessaloniki, Proc. 5th Hel. Symp. Oceanogr. Fish 1 (1997) 67-70.

[31] Saldanha L., Estudo do povoamento dos horizontes superiores da rocha litoral da costa da Arrabida (Portugal), Publ. Mus. Lab. Zool. Anthr. Fac. Cien. Lisboa 5 (1974) 1-382.

[32] Siegel S., Non parametric statistics for the behavioural sciences, McGraw-Hill Kogakusha, Ltd, 1956, 312 p.

[33] Soyer J., Bionomie benthique du plateau continental de la côte catalane française, III: Les peuplements de Copépodes Harpacticoides (Crustacea), Vie milieu 21 (1970) 377-511.

[34] Stirn J., Manual of methods in aquatic environment research, Part 8, Ecological assessment of pollution effects (Guidelines for the F.A.O. (GFCM)/UNEP Joint Coordinated Project on pollution in Mediterranean), F.A.O. Fisheries Technical Paper 209, 1981, 190 p.

[35] Topaloglou B., Kihara K., Community of Mediterranean mussel Mytilus galloprovincialis Lamark, 1819 in the Bosphorus strait, J. Tokyo Univ. Fish. 80 (1993) 113-120.

[36] Tsuchiya M., Nishihira M., Islands of Mytilus edulis as a habitat for small intertidal animals: effect of Mytilus age structure on the species composition of the associated fauna and community organisation, Mar. Ecol. Prog. Ser. 31 (1986) $171-178$.

[37] Tsuchiya M., Bellan-Santini D., Vertical distribution of shallow rocky shore organisms and community structure of mussel beds (Mytilus galloprovincialis) along the coast of Marseilles, France, Mésogée 49 (1989) 91-110.

[38] Tursi A., Matarrese A., Sciscioli M., Vaccarella R., Chieppa G., Variazioni di biomassa nel Mar-Piccolo di Taranto e loro rapporto con i banchi naturali di mitili, Oebalia (1979) 49-70.

[39] Weinberg S., The minimal area problem in invertebrate communities of Mediterranean rocky substrate, Mar. Biol. 49 (1978) 33-40.

[40] Wenner A.M., Crustacean and other invertebrates as indicators of beach pollution, in: Soule D.F., Kleppel G.S. (Eds.), Marine Organisms as Indicators, Springer Verlag, Berlin, 1988, pp. 199-229. 